\title{
Resprouting from roots in four Brazilian tree species
}

\author{
Adriana Hissae Hayashi ${ }^{1}$ \& Beatriz Appezzato-da-Glória ${ }^{2}$ \\ 1. Seção de Anatomia e Morfologia, Instituto de Botânica, C.P. 3005, 01061-970, São Paulo, São Paulo, Brazil; \\ 2. Departamento de Ciências Biológicas, Escola Superior de Agricultura 'Luiz de Queiroz', Universidade de São Paulo, \\ C.P. 09, 13418-900, Piracicaba, São Paulo, Brazil; bagloria@esalq.usp.br
}

Received 27-II-2007. C Corrected 01-II-2009. Accepted 01-III-2009.

\begin{abstract}
Previous studies pointed out that species richness and high density values within the Leguminosae in Brazilian forest fragments affected by fire could be due, at least partially, to the high incidence of root sprouting in this family. However, there are few studies of the factors that induce root sprouting in woody plants after disturbance. We investigated the bud formation on root cuttings, and considered a man-made disturbance that isolates the root from the shoot apical dominance of three Leguminosae (Bauhinia forficata Link., Centrolobium tomentosum Guill. ex Benth, and Inga laurina (Sw.) Willd) and one Rutaceae (Esenbeckia febrifuga (St. Hil.) Juss. ex Mart.). All these species resprout frequently after fire. We also attempted to induce bud formation on root systems by removing the main trunk, girdling or sectioning the shallow lateral roots from forest tree species Esenbeckia febrifuga and Hymenaea courbaril L. We identified the origin of shoot primordia and their early development by fixing the samples in Karnovsky solution, dehydrating in ethyl alcohol series and embedding in plastic resin. Serial sections were cut on a rotary microtome and stained with toluidine blue O. Permanent slides were mounted in synthetic resin. We observed different modes of bud origin on root cuttings: close to the vascular cambium (C. tomentosum), from the callus (B. forficata and E. febrifuga) and from the phloematic parenchyma proliferation (I. laurina). Fragments of B. forficata root bark were also capable of forming reparative buds from healing phellogen formed in callus in the bark's inner side. In the attempt of bud induction on root systems, Hymenaea courbaril did not respond to any of the induction tests, probably because of plant age. However, Esenbeckia febrifuga roots formed suckers when the main trunk was removed or their roots were sectioned and isolated from the original plant. We experimentally demonstrated the ability of four tree species to resprout from roots after disturbance. Our results suggest that the release of apical dominance enables root resprouting in the studied species. Rev. Biol. Trop. 57 (3): 789-800. Epub 2009 September 30.
\end{abstract}

Key words: anatomy, Leguminosae, root buds, Rutaceae, propagation, wood cuttings.

Resprouting is an efficient means for woody plants to regain biomass loss after fire disturbance (Bellingham and Sparrow 2000). However, according to Rodrigues et al. (2004), evaluations of root sprouting in disturbed Seasonal Semideciduous Forests of Southeast Brazil are still very scarce. Rodrigues et al. (2004) studied which species and in what percentage of tree species resprouted from root buds in an urban forest remnant in Brazil (State of São Paulo) seriously affected by frequent fires. According to this study, 27 tree species belonging to 17 families were able to resprout from roots and the most representative was Leguminosae followed by Rubiaceae, Rutaceae, Sapindaceae and Solanaceae. Resprouting from root buds could represent an effective process of spatial reoccupation and vegetative propagation, as sucker shoots have the potential to emerge at variable distances from the main trunk and become independent (Rodrigues et al. 2004). Penha (2004) studied the influence of root suckering on populational characteristics of tree species in another Seasonal Semideciduous Forest fragment in the State of São Paulo and observed young clones 
for Centrolobium tomentosum at fire-disturbed forest areas, whereas no clone was found at the non fire-disturbed forest areas. That high species richness and density values within Leguminosae species, such as Bauhinia forficata and Centrolobium tomentosum, in forest fragments affected by fire disturbances could be due, at least partially, to the high incidence of root resprouting potential in this family (Rodrigues et al. 2004). It is well known that fire can cause severe damages to aerial portion of the main trunk interfering to the apical dominance (Lacey and Johnston 1990), however other factors can induce bud formation on roots like increase in soil temperature (Zasada and Schier 1973), main trunk removing (Lacey and Johnston 1990, Paukkonen et al. 1992), damage on roots (Burrows 1990, Lacey and Johnston 1990, Fraser et al. 2004), and exposing root to light (Lacey and Johnston 1990, Saner et al. 1995). In addition, severe damage to aerial portion of the main trunk probably affects the movement of auxins and cytokinins in the roots (Farmer 1962, Schier 1975). Therefore, bud formation was investigated on root cuttings of three Leguminosae (Bauhinia forficata Link., Centrolobium tomentosum Guill. ex Benth, Inga laurina (Sw.) Willd) and one Rutaceae species (Esenbeckia febrifuga (St. Hil.) Juss. ex Mart.) that resprout frequently in Brazilian forest fragments. Furthermore, bud formation was also induced on root systems through removal of the main trunk, girdling or sectioning the shallow lateral roots of forest tree species Esenbeckia febrifuga and Hymenaea courbaril L.

\section{MATERIALS AND METHODS}

Fragments of Bauhinia forficata root bark and root cuttings of four species (Table 1) were collected from individuals in a Semideciduous Seasonal Forest remnant in Campinas ( $22^{\circ} 55^{\prime} \mathrm{S}$ and $47^{\circ} 05^{\prime} \mathrm{W} ; 22^{\circ} 48^{\prime} \mathrm{S}$ and $47^{\circ} 07^{\prime} \mathrm{W}$ ) and Piracicaba $\left(22^{\circ} 42^{\prime} \mathrm{S}\right.$ and $\left.47^{\circ} 38^{\prime} \mathrm{W}\right)$, in the State of São Paulo, Brazil.

Ten root cuttings (ca. $20 \mathrm{~cm}$ long and $1 \mathrm{~cm}$ in diameter) of each species were planted horizontally in plastic boxes containing sand and kept inside a greenhouse until bud sprouting.

The identification of the origin of shoot primordia and their early development were carried out by fixing the samples in Karnovsky solution (Karnovsky 1965). Samples were dehydrated in ethyl alcohol series and embedded in plastic resin (Leica Historesin). Serial sections (5-7 $\mu \mathrm{m}$ thick) were cut on a rotary microtome and stained with toluidine blue $\mathrm{O}$ (Sakai, 1973). Permanent slides were mounted in synthetic resin.

For the study under field conditions, nursery trees of Hymenaea courbaril L. (Leguminosae - Caesalpinioideae) and Esenbeckia febrifuga 7 and 10 months-old (respectively) from a commercial orchard were planted in an experimental area in December 1998. These species were selected from the sucker-producing roots survey of Rodrigues (1999).

In December 2001, after establishment and growth period of individuals of $H$. courbaril (43 months-old) and Esenbeckia febrifuga (46 months-old) in the field, 11 individuals of each species were left intact (control) or were

TABLE 1

Species studied, locality of collection and accession number in ESA and UEC Herbaria, Brazil

$\begin{array}{lcc}\text { Species } & \text { Locality of collection } & \text { Accession number } \\ \text { Leguminosae } & & \\ \begin{array}{l}\text { Bauhinia forficata } \text { Link (Caesalpinioideae) } \\ \text { Centrolobium tomentosum Guill. ex Benth. (Papilionoideae) }\end{array} & \text { Piracicaba } & \text { ESA 81064; 81065 } \\ \text { Inga laurina } \text { (Sw.) Willd. (Mimosoideae) } & \text { Campinas } & \text { UEC 35772 } \\ \text { Rutaceae } & \text { Campinas } & \text { UEC 35781 } \\ \text { Esenbeckia febrifuga } \text { (St. Hil.) Juss. ex Mart. } & & \text { UEC } 35777\end{array}$


submitted to removal of their main trunk or their shallow lateral roots were sectioned or then girdled by removing the bark (total of 44 individuals per species).

Removal of the main trunk was performed at the height of ca. $15 \mathrm{~cm}$ above the soil surface. For girdling or sectioning of the lateral roots, two roots of each individual (ca. $1.9 \mathrm{~cm}$ diameter for $H$. courbaril and $1.3 \mathrm{~cm}$ for $E$. febrifuga) were selected. Girdling was carried out by removing a bark strip ( $1.5 \mathrm{~cm}$ wide $)$ at a distance of $5 \mathrm{~cm}$ from the stem base. Sectioning was performed at $15 \mathrm{~cm}$ away from the base of the trees with a sharp knife.

\section{RESULTS}

Responses of Hymenaea courbaril and Esenbeckia febrifuga (Fig. 1-8) were different after removal of the main trunk (Fig. 3) or girdling (Fig. 4) or sectioning (Fig. 5) of the shallow lateral roots in study under field conditions.

Individuals of Hymenaea courbaril did not resprout from roots, independently of treatment. On the other hand, Esenbeckia febrifuga originated several suckers from roots when the main trunk was removed (Fig. 6-7) or when lateral roots were sectioned (Fig. 8). Six of 11 individuals of E. febrifuga submitted to the removal of the main trunk originated sucker shoots on roots (Table 2). Shoots developed on several lateral roots, totalizing 89 suckers 61.7 $\mathrm{cm}$ away from the trunk base and at a depth of $1.8 \mathrm{~cm}$ in the insertion point of the sprouts on roots (Table 2). Sometimes, there was a thickening of root on the distal portion of the root sucker.

From 11 individuals with lateral roots sectioned, six resprouted from roots, totalizing 30 sucker sprouts. These suckers were formed generally on the proximal end of the sectioned root, that is, in the side next to the main tree, and, occasionally, along the roots. The average diameter of the roots was $1.3 \mathrm{~cm}$ at a depth of $6.3 \mathrm{~cm}$ in the insertion point of the sprouts on roots and at $17.5 \mathrm{~cm}$ away from the base of the trees (Table 2). These sprouts might develop individually or in clusters.

Individuals of Esenbeckia febrifuga showed no sucker sprout originated on roots from individuals with girdled or intact lateral roots (control).

All studied species produced buds on root cuttings but the mode of bud origin varied among them.

Initially, there was a thickening of certain areas of the root cuttings of Bauhinia forficata and, later, buds emerged through the bark. The gap formed in this region of the root cutting (Fig. 9) extended from the periderm to the secondary xylem, exposing partially the latter (Fig. 10-12). The outer cells of the exposed secondary xylem were ruptured or obliterated in this region. Accumulation of substances inside vessel elements below them could be observed and the tylose formation was intensified (Fig. 11). Healing phellogen developed only in the cut edges of the bark bounding the wounded secondary phloem and became continuous with the phellogen of original periderm of intact areas of the root. The vascular cambium cells

TABLE 2

Sprouting from roots after removal of the main trunk or sectioning the shallow lateral roots of Esenbeckia febrifuga $(N=11)$

$\begin{array}{lcccccc} & \begin{array}{c}\text { Number of } \\ \text { individuals } \\ \text { with sprouts }\end{array} & \begin{array}{c}\text { Total number } \\ \text { of sprouts }\end{array} & \begin{array}{c}\text { Number } \\ \text { of sprouts per } \\ \text { individual }\end{array} & \begin{array}{c}\text { Root } \\ \text { average } \\ \text { diameter }(\mathrm{cm})\end{array} & \begin{array}{c}\text { Root } \\ \text { average } \\ \text { depth }(\mathrm{cm})\end{array} & \begin{array}{c}\text { Average } \\ \text { distance } \\ \text { between sprout } \\ \text { and tree }(\mathrm{cm})\end{array} \\ \text { Main trunk removal } & 6 & 89 & 14.8 & 0.3 & 1.8 & 61.7 \\ \text { Section of root } & 6 & 30 & 5 & 1.3 & 6.3 & 17.5 \\ \text { Control } & 0 & 0 & 0 & - & -\end{array}$



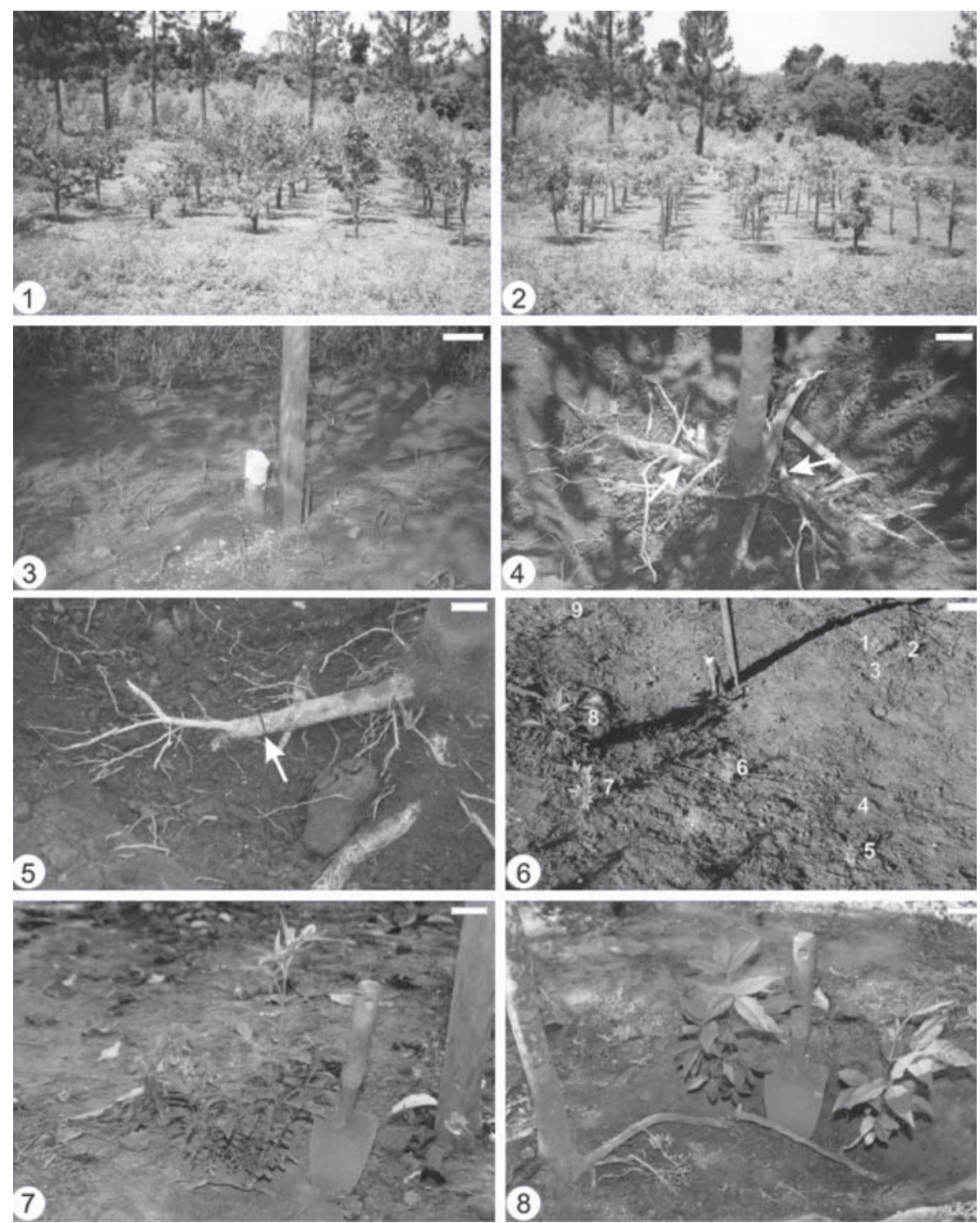

Fig. 1-8. 1-2. Individuals of Hymenaea courbaril and Esenbeckia febrifuga, respectively, growing in experimental area. 3. Main trunk removed at $15 \mathrm{~cm}$ above the soil surface. 4. Girdling of two lateral roots (arrows) at a distance of $5 \mathrm{~cm}$ from the stem base. 5. Lateral root sectioning at $15 \mathrm{~cm}$ away from the base of the tree. 6. Root suckers (numbers 1-9) of E. febrifuga after 6 months of main trunk removal. 7. Detail of a group of E. febrifuga root suckers. 8. Two suckers growing on a sectioned lateral root. Bar $=10 \mathrm{~cm}(3) ; 5 \mathrm{~cm}(4) ; 3 \mathrm{~cm}(5) ; 15 \mathrm{~cm}(6) ; 4.2 \mathrm{~cm}(7-8)$.

next to the gap divided to form a small callus with cells of different size and shape (Fig. 11-12). The vascular cambium was restored from the differentiation of the callus cells in some areas of the root and became continuous with the vascular cambium of intact areas.
Adventitious buds, which can grow in opposite sides (Fig. 12), developed from meristemoids formed in the callus edge.

Root fragments of Bauhinia forficata collected at random from the field (Fig. 13) were constituted only by bark, that is, periderm and 


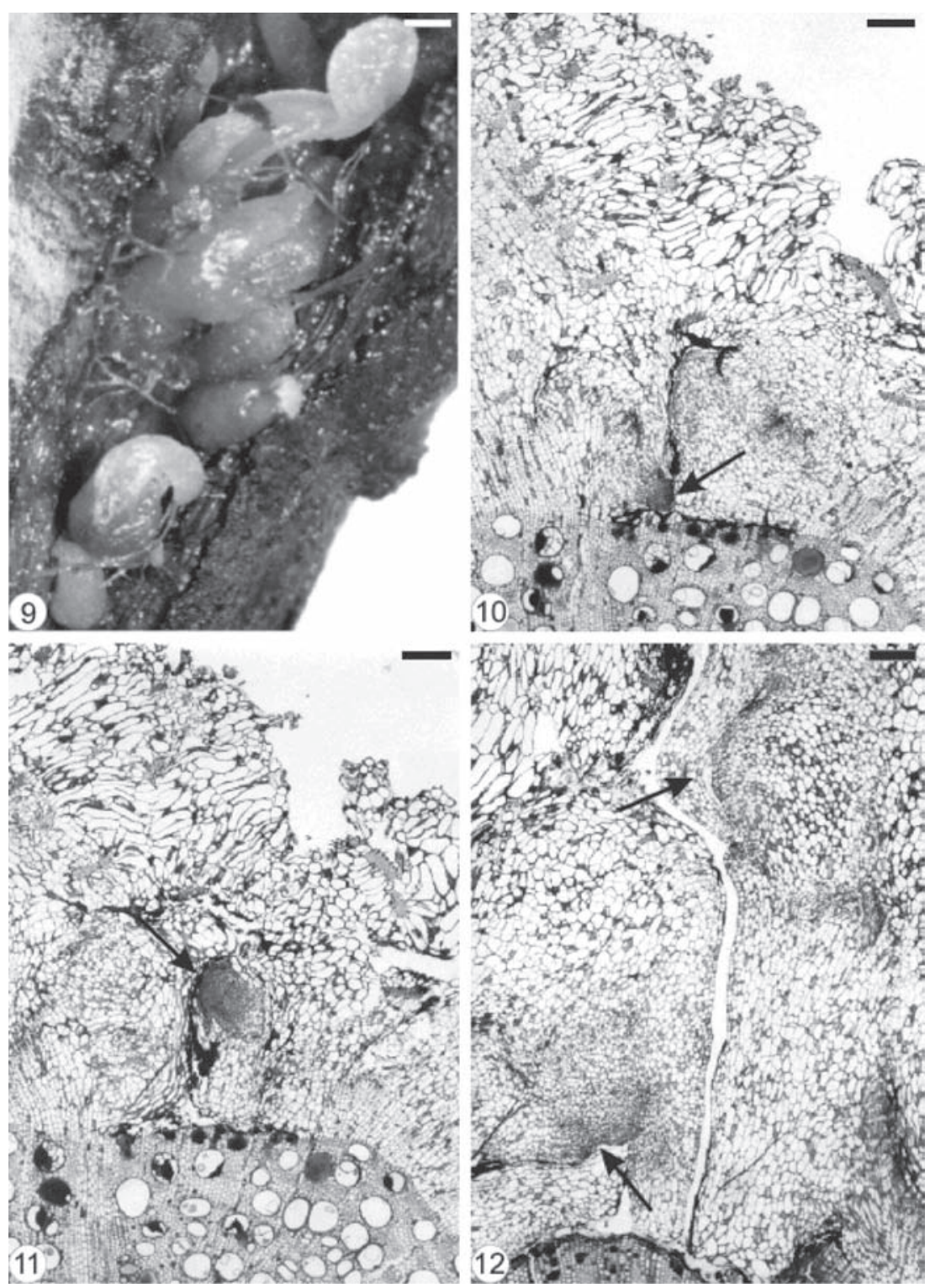

Fig. 9-12. 9. Buds forming on root cutting of Bauhinia forficata. 10-11 Transverse sections of root cuttings showing meristemoids (arrows) on opposite sides originated from the callus. 12. Two buds on opposite sides (arrows) originated from the meristemoid development. Bar $=870 \mu \mathrm{m}(9) ; 200 \mu \mathrm{m}(10-12)$.

secondary phloem (Fig. 14). Parenchymatic cells of the secondary phloem on the opposite side of the original periderm elongated and divided to form a callus (Fig. 14) bordering wounded surface after debarking. Cells of peripherical region in the callus and in all injured secondary phloem differentiated into healing phellogen continuous with the phellogen of existing original periderm. Buds developed exogenously at the periphery of the callus (Fig. 15) from meristemoids originated from cell divisions of the healing phellogen. Vascular nodules were formed next to the site 


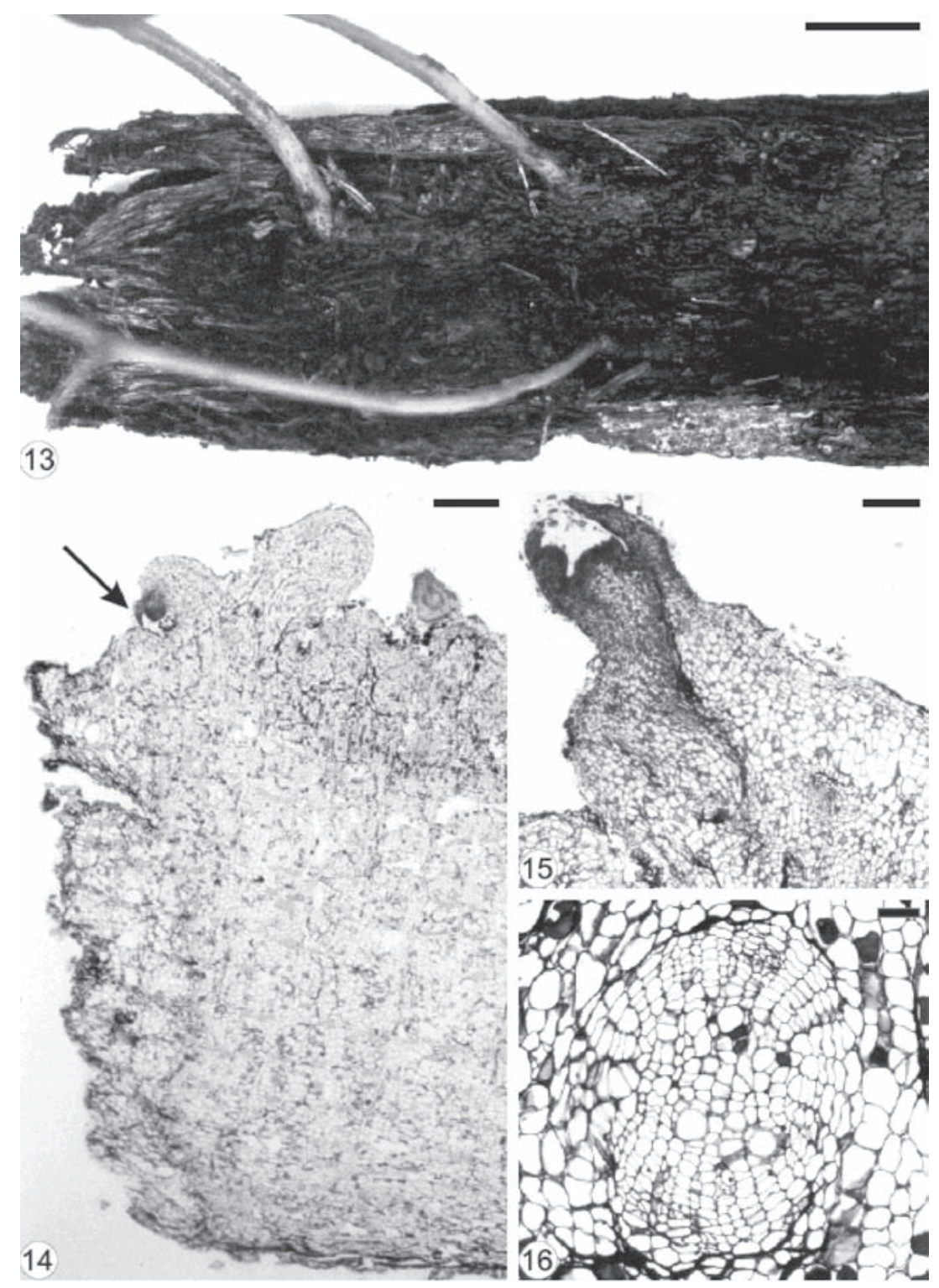

Fig. 13-16. Root bark fragment of Bauhinia forficata collected from the field. 13. Inner surface of the root bark showing the stem base of three suckers. 14-16. Transverse sections of the root bark. 14. General view of the root bark showing the periderm, the callus originated from the parenchyma of the secondary phloem, and a shoot bud (arrow) developed from this callus. 15. Detail of a shoot bud and its vascular connection with the callus. 16. Vascular nodule responsible for the connection between bud and callus. Bar = $1 \mathrm{~cm}(13) ; 450 \mu \mathrm{m}$ (14); $200 \mu \mathrm{m}$ (15); $35 \mu \mathrm{m}$ (16).

of bud emergence and were constituted by the cylindrical vascular cambium producing phloem to the outside and xylem to the inside part of the ring. The vascular connection between bud and callus was made via this nodule (Fig. 16).
Centrolobium tomentosum buds developed near the vascular cambium (Fig. 17) and Esenbeckia febrifuga buds originated from the callus (Fig. 18-23) in injured and non-injured areas of the cutting. The differentiation of 
the vascular tissues between the bud and root was acropetal in $C$. tomentosum. Buds of E. febrifuga formed in the callus periphery (Fig. 19-22) developed from cell divisions of pericycle and phloem parenchyma (Fig.
22-23) and established vascular connection with the root by acropetal and basipetal differentiation of vascular tissues (Fig. 23-25). The acropetal differentiation was due to meristem formation which was named as
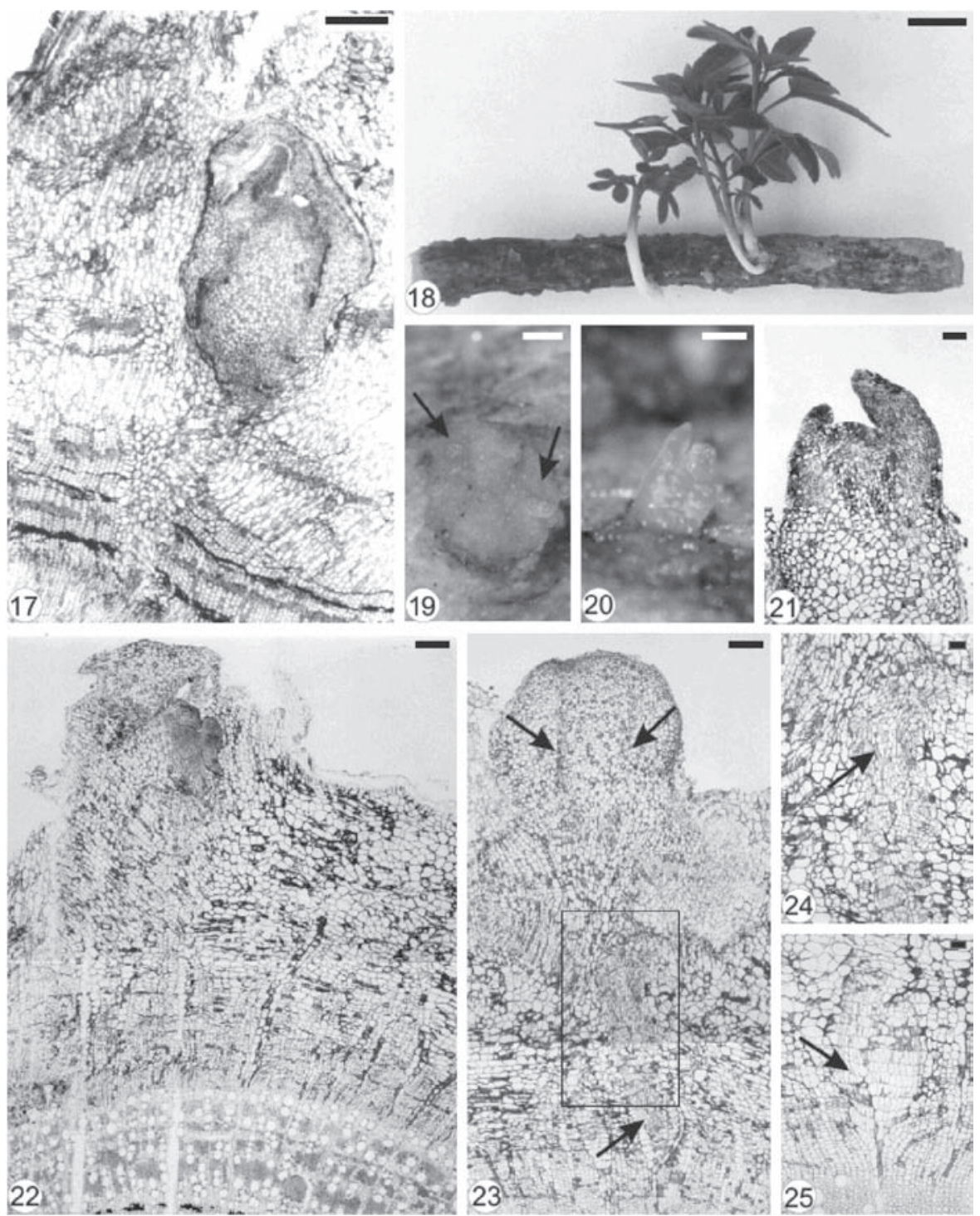

Fig. 17-25. 17. Transverse section of root cuttings of Centrolobium tomentosum showing a bud developed near vascular cambium. 18-25. Root cuttings of Esenbeckia febrifuga. 18. Suckers developed along the root cutting. 19. Bud development (arrows) from the callus in non-injured area of the cutting. 20. Bud originated from the callus formed in injured area of the cutting. 21. Detail of a bud. 22. Bud originated from the callus. 23. Acropetal and basipetal differentiation of the vascular tissues connecting bud and root. 24. Detail of the area indicated in Figure 23 showing vascular tissues (arrow). 25. Wide ray in the secondary phloem near the vascular cambium showing the vascular connection meristem (arrow). Bar $=500 \mu \mathrm{m}(17)$; $1 \mathrm{~cm}$ (18); $620 \mu \mathrm{m}$ (19); $510 \mu \mathrm{m}$ (20); $75 \mu \mathrm{m}(21,24-25) ; 200 \mu \mathrm{m}(22-23)$. 
vascular connection meristem (Fig. 23-25). This meristem was formed near the periphery of wide rays in the secondary phloem, whose dilatation is due to anticlinal cell divisions restricted to bud site (Fig. 23). In this dilated area, vascular cambium produced more parenchymatic cells than other cell types in the secondary xylem.

Inga laurina had exogenous buds (Fig. 26-27) originated from meristemoids formed in the proliferated phloematic parenchyma located just below the sclerenchymatic ring (Fig.
28-29). These meristemoids were very close to each other (Fig. 28) or isolated (Fig. 29) and developed into buds (Fig. 30), confirming the proximity of the shoots in the root cutting (Fig. 26-27). Vascular tissues developed between bud and root cutting and then the sclerenchymatic ring and periderm were ruptured by the emergence of the bud (Fig. 29-30).

It was not possible to verify the direction of vascular differentiation between bud and root cutting in Inga laurina and Bauhinia forficata.

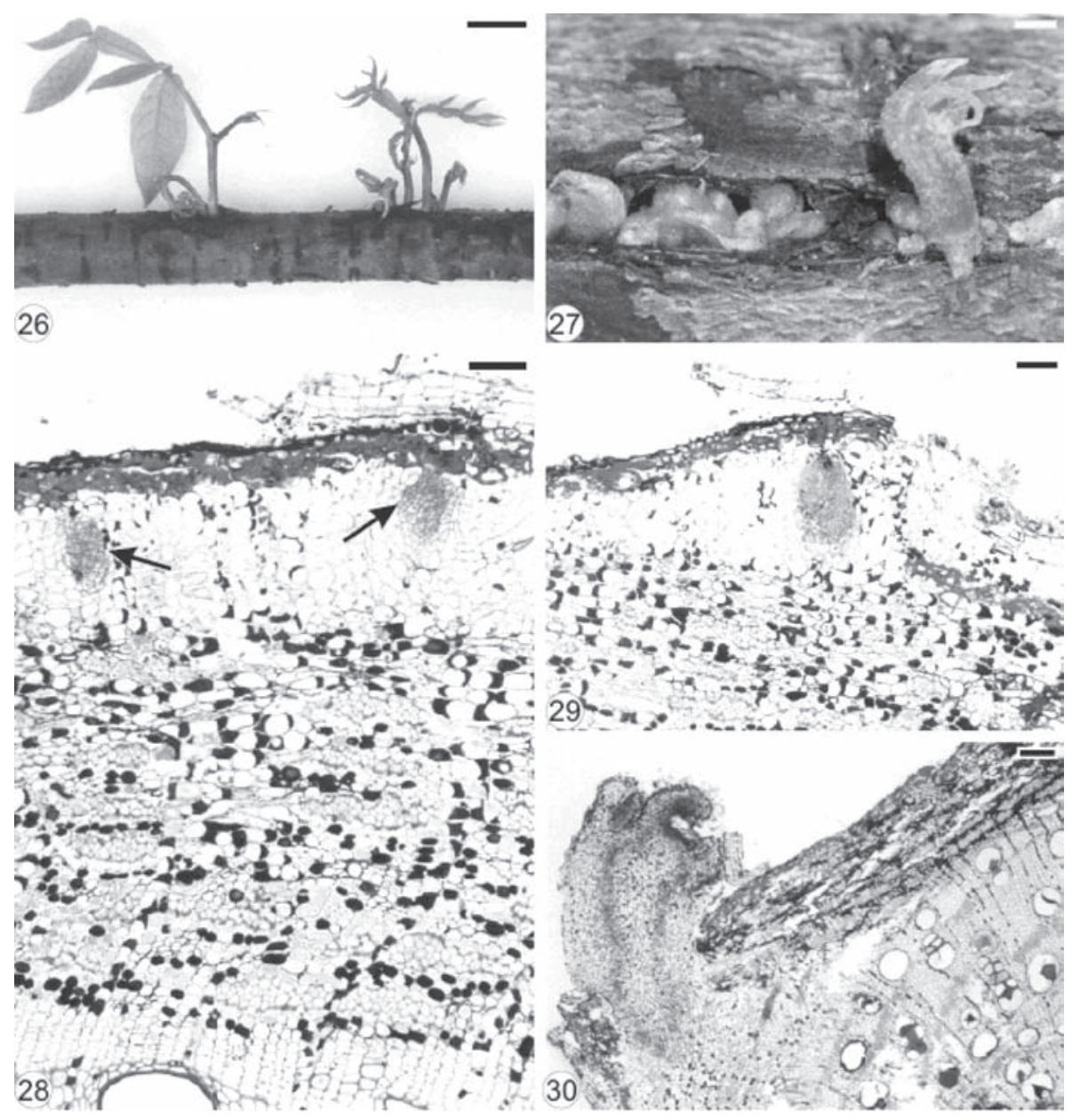

Fig. 26-30. Root cuttings of Inga laurina. 26. Suckers in different stages of development. 27. Bud development. 28-30. Transverse sections of the root cutting. 28. Two meristemoids (arrows) originating from the proliferation of the phloematic parenchyma. 29. Isolated meristemoid located just below the sclerenchymatic ring. 30. Rupture of sclerenchymatic ring and periderm due to bud emergence. Bar $=1 \mathrm{~cm}(26) ; 1200 \mu \mathrm{m}(27) ; 75 \mu \mathrm{m}(28-29) ; 200 \mu \mathrm{m}(30)$. 


\section{DISCUSSION}

Disturbance such as herbivore, fire, floods, hurricanes, landslides, or logging may kill or induce resprouting of woody plants (Bond and Midgley 2003) after causing damages to aerial or subterranean organs (Lacey and Johnston 1990, Paukkonen et al. 1992, Bosela and Ewers 1997).

The majority of tree species produces secondary trunks only when apical control is destroyed or blocked by some extrinsic factor (Del Tredici 2001). Even though growth is the result of a complex interaction of auxins and other hormones (Schier 1975), heavy root sprouting following lethal aboveground disturbances can be due to the interruption of auxin transport from stems to roots and the subsequent release of buds from hormonal suppression (Farmer 1962, Schier 1975). Indeed, after collection of root cuttings, auxin levels drop rapidly with time (Eliasson 1971), and sucker development can proceed. Our results support the results found in these studies, because all studied species produced buds on root cuttings and there was a great number of suckering on roots in Esenbeckia febrifuga when the main trunk was cut or when the shallow lateral roots were sectioned. However, the individuals submitted to the treatment of girdling of the lateral roots did not sprout. According to Jones (1998), auxin transport in root is predominantly down through the central stele and after auxin reaches the root tip, it is distributed back upward along the root in the epidermis and subtending cortical cells. Thus, the removal of the strip of bark has not been efficient to prevent the auxin transport along the root.

We believe that Hymenaea courbaril did not produce suckers on roots, as it does in native ecosystems due to the age of individuals. E. febrifuga is an understory species, while $H$. courbaril is a late secondary species (Rodrigues et al. 2004). They were in different physiological phases during our observations: E. febrifuga was already in the reproductive phase, whilst $H$. courbaril was in the vegetative phase. According to Zimmerman (1972), flower production is the first sign for adult phase, even though the end of the juvenile phase and the first flowering may not coincide. $H$. courbaril individuals were 3 years 7 months old when they were submitted to resprout induction treatments and they did not produce flowers until the end of our observations (4,5 years old). Probably, H. courbaril will express the capacity of root sprouting late in plant development. This could explain why root sprouting was not observed during the analyzed period, while it is usually observed in adult plants growing in native environment (Rodrigues et al. 2004). Martínková et al. (2004) also observed that plant age was an important factor influencing resprouting ability in short-life herb Rorippa palustris (Brassicaceae). The authors suggested that resprouting ability in the vegetative stage of the plant's life cycle is age-dependent and plants must reach a certain age to be able to resprout from roots.

The mode of bud origin on roots varied among the studied species. Buds originated from the callus in Bauhinia forficata and Esenbeckia febrifuga or they developed near the vascular cambium in Centrolobium tomentosum and from the proliferated phloematic parenchyma in Inga laurina. The callus formation prior to bud origin was also verified in Fagus grandifolia Ehrh. (Fagaceae) by Jones and Raynal (1986) and in Machaerium stipitatum (DC.) Vog. (Leguminosae) by Hayashi et al. (2001). According to Sharples and Gunnery (1933), when the callus extended to fill the wounding region in Hibiscus rosa-sinensis L. and Hevea brasiliensis Müll. Arg., phellogen and vascular cambium were completely restored differentiating from areas near the phellogen and vascular cambium of undamaged portion of the bark into the central region of the callus until they became continuous.

In the injured areas of Esenbeckia febrifuga cuttings, callus formation occurred on wounded surface. Nevertheless, these two meristems (phellogen and vascular cambium) did not regenerate. However, callus filled partially the gap formed in the root bark in Bauhinia forficata cuttings and in some areas the vascular 
cambium was restored from the differentiation of the callus cells becoming continuous with the cambium of intact areas while the phellogen differentiated only in the cut edges of the bark bounding the wound tissue.

Fragments of $B$. forficata root bark developed buds from the healing phellogen formed in the callus periphery. Similar process was observed by Mello et al. (2000) when hypocotyl segments of this specie were cultivated in vitro, promoting bud differentiation from superficial layers of callus formed on the explant surface.

Vascular connection between buds and root cutting of Esenbeckia febrifuga was established by an acropetal and basipetal differentiation of vascular tissues as observed in Machaerium stipitatum (Hayashi et al. 2001). The acropetal vascular differentiation of E. febrifuga buds was associated with the dilatation of phloematic ray as observed in the adventitious roots of stem cuttings of Acacia baileyana $\mathrm{F}$. Muell. (Schwarz et al.1999). This dilatation of phloematic ray in E. febrifuga always occurred on opposite side to the bud, but it was not associated with bud origin as verified in stems of Tilia platyphyllos, Fraxinus excelsior and Couroupita guianensis (Fink 1983) and in Ulmus americana (Angeles et al. 1986). In the root bark fragments of Bauhinia forficata, the vascular connection between buds and callus occurred by vascular nodules formed next to the site of bud emergence. This type of connection between bud and its origin tissue was also observed by Appezzato-da-Glória and Estelita (1995) in tuberous root of Mandevilla illustris (Vell.) Woodson.

All studied species showed reparative root buds, as they were exogenous in origin and did not have bud traces produced in the secondary xylem (Bosela and Ewers 1997). Reparative buds form de novo in response to senescence, injuries or other types of disturbance of the root, and may therefore be initiated at any period of root secondary growth (Bosela and Ewers 1997). According to the authors, the presence of additional buds, formed during the early growth of uninjured roots, is a characteristic related to clonal spread. Therefore, it is possible that individuals of Centrolobium tomentosum in natural conditions produce additional and reparative buds as Penha (2004) confirmed young clones through RAPD molecular markers for this species in forest fragments. Thus, the great number of tree species of Leguminosae in forest fragments affected by disturbances can be probably due to their ability of root-sprouting (Rodrigues et al. 2004).

Root suckering promotes vegetative propagation because it allows spreading of individuals from the original site of establishment, promoting the colonization of new sites (Bond and Midgley 2003, Del Tredici 2001). Therefore, the capacity of producing reparative buds from underground systems, as demonstrated here, shows the vegetative reproduction potential of these species as already discussed by Rodrigues et al. (2004). In addition, it emphasizes its importance in the process of spatial reoccupation of fire events. The advantages of root sprouting over sexual reproduction are that sprouts have an established root system supplying water and reserve compounds (Simões and Marques 2007). Some studies were carried out in tropical forests in order to understand process of root sprouting of tree species in disturbed environments (e.g., Hayashi et al. 2001, Penha 2004, Rodrigues et al. 2004). Data from such studies may direct management plans by recommending natural or artificial propagation to restore forest structure and function (Simões and Marques 2007).

\section{ACKNOWLEDGMENTS}

We are grateful to the Instituto Agronômico de Campinas and Fundação José Pedro de Oliveira in giving permission to collect plant materials. This research was supported by FAPESP, CAPES and CNPq.

\section{RESUMEN}

Estudios anteriores señalaron que la alta riqueza de especies de Leguminosae en fragmentos de bosques afectadas por el fuego podría deberse, al menos parcialmente, 
a la alta incidencia de brotes de raíz en esta familia. Sin embargo, existen pocos estudios. Investigamos la formación de brotes en tres Leguminosae (Bauhinia forficata Link., Centrolobium tomentosum Guill. ex Benth, e Inga laurina (Sw.) Willd) y una Rutaceae (Esenbeckia febrifuga (St. Hil.) Juss. ex Mart.). Todas estas especies suelen rebrotar después de los incendios. También hicimos cortes experimentales en árboles forestales: Esenbeckia febrifuga e Hymenaea courbaril L. Observamos tres orígenes: cerca del cambium vascular (C. tomentosum), desde el callo (B. forficata y E. febrifuga) y de parénquima (I. laurina). Hymenaea courbaril no respondió a ninguna de las pruebas de inducción, probablemente debido a la edad de la planta. Sin embargo, las raíces de Esenbeckia febrifuga forman retoños tras retirar el tronco o separar sus raíces. Hemos demostrado experimentalmente la capacidad de las cuatro especies de árbol de rebrotar a partir de sus raíces tras una perturbación grave.

Palabras clave: anatomía, estacas leñosas, Leguminosae, propagación vegetativa, Rutaceae, yema radical.

\section{REFERENCES}

Angeles, G., R.F. Evert \& T.T. Kozlowski. 1986. Development of lenticels and adventitious roots in flooded Ulmus americana seedlings. Can. J. For. Res. 16: 585-590.

Appezzato-da-Glória, B. \& M.E.M. Estelita. 1995. Caracteres anatômicos da propagação vegetativa de Mandevilla illustris (Vell.) Woodson e de M. velutina (Mart. ex Stadelm.) Woodson - Apocynaceae. In Congresso da Sociedade Botânica de São Paulo, 9., Ilha Solteira, 1995. Anais. Ilha Solteira: SBSP, p. $5-13$.

Bellingham, P.J. \& A.D. Sparrow. 2000. Resprouting as a life history strategy in woody plant communities. Oikos 89: 409-416.

Bond, W.J. \& J.J. Midgley. 2003. The evolutionary ecology of sprouting. Int. J. Plant Sci. 164: S103-S114.

Bosela, M.J. \& F.W. Ewers. 1997. The mode of origin of root buds and root sprouts in the clonal tree Sassafras albidum (Lauraceae). Am. J. Bot. 84: 1466-1481.

Burrows, G.E. 1990. Anatomical aspects of root bud development in hoop pine (Araucaria cunninghamii). Aust. J. Bot. 38: 73-78.

Del Tredici, P. 2001. Sprouting in temperate trees: a morphological and ecological review. Bot. Rev. 67: 121-140.

Eliasson, L. 1971. Growth regulators in Populus tremula. III. Variation of auxin and inhibitor level in roots in relation to root sucker formation. Physiol. Plantarum 25: 118-121.

Farmer Jr, R.E. 1962. Aspen root sucker formation and apical dominance. For. Sci. 8: p.403-410.

Fink, S. 1983. The occurrence of adventitious and preventitious bud within the bark of some temperate and tropical trees. Am. J. Bot. 70: 532-542.

Fraser, E.C., V.J. Lieffers \& S.M. Landhäusser. 2004. Wounding of aspen roots promotes suckering. Can. J. Bot. 82: 310-315.

Hayashi, A.H., A.S. Penha, R.R. Rodrigues \& B. Appezzatoda-Glória. 2001. Anatomical studies of shoot budforming roots of Brazilian tree species. Aust. J. Bot. 49: 745-751.

Jones, A.M. 1998. Auxin transport: down and out and up again. Science 282: 2201-2202.

Jones, R.H. \& D.J. Raynal. 1986. Spatial distribution and development of root sprouts in Fagus grandifolia (Fagaceae). Amer. J. Bot. 73: 1723-1731.

Karnovsky, M.J. 1965. A formaldehyde-glutaraldehyde fixative of high osmolality for use in electron microscopy. J. Cell Biol. 27: 137-138.

Lacey, C.J. \& R.D. Johnston. 1990. Woody clumps and clumpwoods. Aust. J. Bot. 38: 299-334.

Martínková, J., M. Kočvarová \& J. Klimešová. 2004. Resprouting after disturbance in the short-lived herb Rorippa palustris (Brassicaceae): an experiment with juveniles. Acta Oecol. 25: 143-150.

Mello, M.O., M. Melo \& B. Appezzato-da-Glória. 2000. Bauhinia forficata Link Shoot regeneration: histological analysis of organogenesis pathway. Braz. arch. biol. technol. 43: 431-436.

Paukkonen, K., A. Kauppi \& A. Ferm. 1992. Root and stump buds as structural faculties for reinvigoration in Alnus incana (L.) Moench. Flora 187: 353-367.

Penha, A. S. 2004. Influência da propagação vegetativa a partir de raízes gemíferas nas características populacionais de espécies arbóreas em fragmentos de Florestas Estacionais Semideciduais. Ph. D. Thesis; Universidade Estadual de Campinas, Campinas, Brazil. 135 p.

Rodrigues, R.R. 1999. Colonização e enriquecimento de um fragmento florestal urbano após a ocorrência de fogo, Fazenda Santa Elisa, Campinas, SP: avaliação temporal da regeneração natural (66 meses) e do crescimento (51 meses) de 30 espécies florestais plantadas em consórcios sucessionais. Thesis; Universidade de São Paulo, Piracicaba, Brazil. 167 p. 
Rodrigues, R.R., R.B. Torres, L.A.F. Matthes \& A.S. Penha. 2004. Tree species sprouting from root buds in a Semideciduous Forest affected by fires. Braz. arch. biol. technol. 47: 127-133.

Sakai, W.S. 1973. Simple method for differential staining of paraffin embedded plant material using toluidine blue O. Stain Tech. 48: 247-249.

Saner, M.A., D.R. Clements, M.R. Hall, D.J. Doohan \& C.W. Crompton. 1995. The biology of Canadian weeds. 105. Linaria vulgaris Mill. Can. J. Plant Sci. 75: 525-537.

Schier, G.A. 1975. Promotion of sucker development on Populus tremuloides root cuttings by an antiauxin. Can. J. For. Res. 5: 338-340.
Schwarz, J.L., P.L. Glocke \& M. Sedgley. 1999. Adventitious root formation in Acacia baileyana F. Muell. J. Hort. Sci. Biotech. 74: 561-565.

Sharples, A. \& H. Gunnery. 1933. Callus formation in Hibiscus rosa-sinensis L. and Hevea brasiliensis Müll. Arg. Ann. Bot. 47: 827-839.

Simões, C.G. \& M.C.M. Marques. 2007. The role of sprouts in the restoration of Atlantic Rainforest in southern Brazil. Rest. Ecol. 15: 53-59.

Zasada, J.C. \& G.A. Schier. 1973. Aspen root suckering in Alaska: effect of clone, collection date and temperature. Northwest Sci. 47: 100-104.

Zimmerman, R.H. 1972. Juvenility and flowering in wood plants: a review. HortScience 7: 447-455. 